ARTICLE

\title{
Combined ground and aerial measurements resolve vent-specific gas fluxes from a multi-vent volcano
}

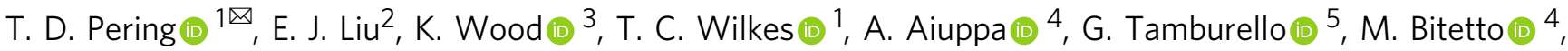 \\ T. Richardson ${ }^{3}$ \& A. J. S. McGonigle $e^{1,6,7}$
}

Volcanoes with multiple summit vents present a methodological challenge for determining vent-specific gas emissions. Here, using a novel approach combining multiple ultraviolet cameras with synchronous aerial measurements, we calculate vent-specific gas compositions and fluxes for Stromboli volcano. Emissions from vent areas are spatially heterogeneous in composition and emission rate, with the central vent area dominating passive emissions, despite exhibiting the least explosive behaviour. Vents exhibiting Strombolian explosions emit low to negligible passive fluxes and are $\mathrm{CO}_{2}$-dominated, even during passive degassing. We propose a model for the conduit system based on contrasting rheological properties between vent areas. Our methodology has advantages for resolving contrasting outgassing dynamics given that measured bulk plume compositions are often intermediate between those of the distinct vent areas. We therefore emphasise the need for a vent-specific approach at multi-vent volcanoes and suggest that our approach could provide a transformative advance in volcano monitoring applications.

\footnotetext{
${ }^{1}$ Department of Geography, University of Sheffield, Sheffield S10 2TN, UK. ${ }^{2}$ Department of Earth Sciences, University College London, London WC1E 6BS, UK. ${ }^{3}$ Department of Aerospace Engineering, University of Bristol, Bristol BS8 1TR, UK. ${ }^{4}$ DiSTeM, Università di Palermo, via Archirafi, 36,90123 Palermo, Italy. ${ }^{5}$ Istituto Nazionale di Geofisica e Vulcanologia, Sezione di Bologna, Via Donato Creti, 12, 40128 Bologna, Italy. ${ }^{6}$ School of Geosciences, the University of Sydney, Camperdown, NSW 2006, Australia. 7 Faculty of Health, Engineering and Sciences, University of Southern Queensland, Toowoomba, QLD 4350, Australia. ${ }^{凶}$ email: t.pering@sheffield.ac.uk
} 
Ex: xplosive eruptions are driven largely by the rapid exsolution of magmatic volatiles (mainly $\mathrm{H}_{2} \mathrm{O}, \mathrm{CO}_{2}$ and $\mathrm{SO}_{2}$ ), which exsolve from ascending and decompressing magmas at different depths corresponding to their respective solubilities in silicate melts ${ }^{1-6}$. Gas ratios measured in the emitted vapour phase at the surface thus provide direct constraints on the depth of degassing (i.e. equilibrium saturation pressure), and therefore directly inform our understanding of subsurface magmatic systems $s^{5,7-11}$. Abrupt changes in gas ratios, such as $\mathrm{CO}_{2} / \mathrm{SO}_{2}$, have been recorded prior to large eruptions $\mathrm{s}^{9,11-14}$ or changes in the style of activity ${ }^{15,16}$, and therefore contribute to the forecasting of volcanic activity. Together with independent constraints on $\mathrm{SO}_{2}$ emission rates from remote sensing (UV/IR imaging or spectroscopy ${ }^{17-25}$ ); in situ measurements of gas composition enable quantification of total volatile emission rates from volcanoes ${ }^{14,26-30}$.

At volcanoes where there is only a single degassing vent, such as Villarrica (Chile) and Masaya (Nicaragua), procedures for determining $\mathrm{SO}_{2}$ emission rates and total volatile emissions are relatively well established. However, volcanoes with multiple degassing vents or fumaroles in close proximity present additional challenges, particularly if one or more vents exhibit explosive activity thereby restricting measurements to the crater $\operatorname{rim}^{8,15,31,32}$. At these multi-vent systems, differentiating between emissions from each vent or fumarole can be difficult due to a combination of rapid mixing between plumes and restricted viewing geometries for remote measurements. Commonly, therefore, only bulk plume measurements are recorded and the contribution of each vent to the overall degassing flux remains unconstrained. This uncertainty is particularly problematic when different vents are characterised by contrasting eruptive behaviours and degassing styles, and thus likely exhibit distinct gas signatures. Without vent-specific gas compositions and fluxes, critical information is lost that can inform not only our understanding of the subsurface magmatic system, but also the factors controlling variability in eruptive style.

The on-going development of Unoccupied Aerial System (UAS)-mounted gas sampling now enables in situ aerial measurements of gas concentrations in remote, high altitude or otherwise inaccessible volcanic plumes ${ }^{30,33-37}$ with increased spatial resolution and reduced costs/logistics compared to conventional aircraft surveys ${ }^{14}$. Until now, this UAS approach has yet to be integrated synchronously with the ground-based instrumentation needed to derive contemporaneous fluxes for all gas species in a multi-vent setting. The need for more spatiallyresolved gas measurements is particularly important at persistently degassing volcanoes known to exhibit rapid shifts from passive to explosive degassing behaviour. Here, we present synchronous UV camera and aerial Multiple Gas Analyser System (Multi-GAS) measurements of degassing at the archetypal multivent volcano, Stromboli (Aeolian Islands, Sicily, Italy). By isolating gas compositions and emission rates from distinct degassing centres, and interpreting these data in the context of published constraints from other geophysical parameters, we contribute further insight into the shallow degassing processes and drivers of Strombolian explosions at this volcano.

\section{Results}

Stromboli volcano. Stromboli is a composite multi-vent stratovolcano characterised by low viscosity shoshonitic basalts that enable effective gas-melt separation, and thus the persistent release of gases. The summit area of Stromboli is characterised by a broad crater terrace comprising multiple active vents. The number and spatial distribution of the three main degassing areas (see Fig. 1), and their eruptive characteristics, are dynamic and vary on timescales from hours-days to months-years ${ }^{38-43}$. On the basis of detailed analysis of jet dynamics and vent migration in the period 2005-2009, a dual categorisation of the crater terrace has been proposed, $\mathrm{N}$ and $\mathrm{SW}+\mathrm{C}$ vent areas ${ }^{42}$.

Stromboli displays distinct modes of degassing: Passive degassing accounts for $\sim 77 \%$, while non-explosive active degassing ('puffing') and Strombolian explosions together account for $\sim 23 \% 24,38,44$. All three degassing behaviours are often observed in parallel at different vents ${ }^{32,38,39,42,44}$. Strombolian explosions are short-duration, low to moderate intensity explosions, driven by the rapid expansion of Taylor bubbles (also known as gas slugs) and the subsequent impulsive ejection of gas and pyroclastic material $^{45-47}$. Alternative models have also been proposed whereby gas slugs are formed within a crystal-rich plug ${ }^{48,49}$. Puffing is similarly associated with the rapid ejection of gases but from smaller Taylor or cap bubbles and therefore of lower intensity $38,39,41,50,51$. Passive degassing refers to the near-

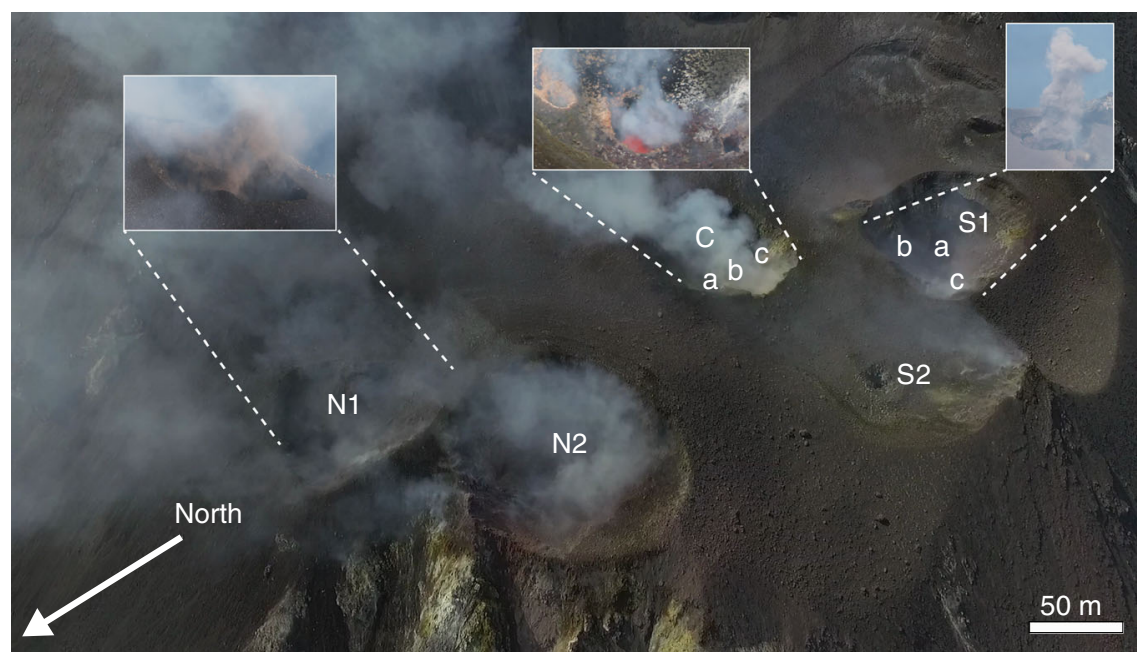

Fig. 1 Stromboli volcano summit area. Multi-vent structure of the crater terrace of Stromboli, imaged during a UAS overflight on 6 June 2018 . Indicated are main degassing areas (N Northern, C Central and S Southern) with numbers indicating separate vents. In response to the distinct eruptive behaviour and degassing characteristics observed, we retain these as separate vent areas rather than adopt the dual characterisation ( $N$ and SW $+\mathrm{C}$ ) previously proposed. Lowercase letters indicate the location of individual intracrater vents where more than one is present. Inset are images of explosions from vents $\mathrm{N} 1$ and $\mathrm{S1}_{\mathrm{a}}$, and incandescence and passive degassing within $\mathrm{C}_{\mathrm{b}}$. 
continuous non-explosive release of gases, again with no pyroclastic material. In addition to these three background behaviours, Stromboli occasionally exhibits major explosions and paroxysms of greater intensity, which generate pyroclastic flows and widespread tephra fallout ${ }^{52,53}$. Two major explosions occurred on 3 July 2019 and 28 August 2019, both preceded by lava efflux from all open vents (INGV Special Bulletins, for July and August); these were the largest explosions recorded since 2007. Given the popularity of Stromboli as a tourist destination, improving our understanding of what drives such dynamic evolution of vent behaviour, and particularly rapid passive to explosive transitions, is of critical importance for hazard assessment ${ }^{54}$.

The summit area and eruptive activity. All vent areas (N, C and S) were active during our period of observation 4-12 June 2018 (Supplementary Movie 1). Here, because of the distinct eruptive behaviour and degassing characteristics observed, we retain these as separate vent areas rather than adopt the dual characterisation $(\mathrm{N}$ and SW $+\mathrm{C}$ ) previously proposed (Fig. 1). The northern vent area (N) comprised two degassing centres; N1 and N2, which both exhibited Strombolian explosions several times every hour. Explosions from N1 were impulsive and energetic, and ejected ash-rich jets to heights of several hundred metres above the vent. No observable passive degassing occurred between explosions, indicating possible sealing of the magmatic column. In contrast, activity at N2 was dominated by continuous passive degassing with occasional low energy ash exhalations that reached only a few tens of metres above the vent before being dispersed downwind. Activity in the southern and central $(\mathrm{S}+\mathrm{C})$ vent area was focused at three main vents, which we refer to as $\mathrm{C}, \mathrm{S} 1$ and S2. However, additional intracrater vents exhibiting low level passive degassing were visible within the main S1 and $\mathrm{C}$ depressions, and these are annotated on Fig. 1. Activity at S1 and S2 was dominated by Strombolian explosions occurring several times every hour, either at both vents simultaneously or at a single vent in isolation.

It was noted that no clear systematic relationship was evident in the relative timings of explosions from the $\mathrm{N}, \mathrm{S}$ and $\mathrm{C}$ vent areas. Explosive activity at $\mathrm{S} 1$ included both ash-free gas exhalations and low to moderately energetic ash-rich explosions. Persistent inter-explosive passive degassing was visible from $S 1_{a}$, with unresolvable contributions from $S 1_{b}$ and $S 1_{c}$. A UAS overflight above S1 showed that during a typical ash-rich explosion, explosive gas release at one vent location preceded by $\sim 1 \mathrm{~s}$ doming of the ground surface and pyroclast ejection at a second position several metres away (Supplementary Movie 1). Interestingly, this implies that a high proportion of the ash released during Strombolian explosions is derived from recycled material covering the vent area ${ }^{55}$ and has significant implications for Strombolian explosion dynamics ${ }^{56,57}$.

Explosions from S2 were comparatively energetic with rapid gas expulsion velocities, likely amplified by the small vent diameter of only a few metres, and contained no visible pyroclasts (including ash, lapilli or bombs). No passive degassing from S2 was detected between explosions. The central vent area (C) was persistently degassing during the period of observation, and provided the most sustained contribution to the bulk plume. Three discrete vents several metres in diameter $\left(\mathrm{C}_{\mathrm{a}-\mathrm{c}}\right)$ were visible within the vent area, each characterised by regular puffing activity that often became stronger and more regular following an explosion at either S1 or S2 (Supplementary Movie 1). Incandescence and occasional spattering activity was observed at $C_{b}$ on 7 June, during which time degassing was reduced or absent at the other two vents.
$\mathrm{SO}_{2}$ emission rates. UV camera measurements from targeted viewing angles allowed the determination of vent-specific $\mathrm{SO}_{2}$ emission rates from four vents (S1, S2, C and N2; see Fig. 2). We observed negligible $\mathrm{SO}_{2}$ from $\mathrm{N} 1$ (except during explosions, during which the acquisition was compromised by ash emission), suggesting that passive $\mathrm{SO}_{2}$ emissions were low and at most at the detection limit of the UV camera. Emission traces are presented in Fig. 3, with our measurements summarised in Table 1. Most of the $\mathrm{SO}_{2}$ emissions emanated from area $\mathrm{C}$, which accounted for $\sim 62-70 \%$ of total $\mathrm{SO}_{2}$ emissions (assuming that $\mathrm{SO}_{2}$ emissions from $\mathrm{N} 1$ are negligible). $\mathrm{SO}_{2}$ emissions on $04 / 06 / 18$ are $\sim 1.62-1.94 \mathrm{~kg} \mathrm{~s}^{-1}$ $\left(\sim 140-168 \mathrm{t} \mathrm{d}^{-1}\right)$, and on $07 / 06 / 18 \sim 1.61-2.04 \mathrm{~kg} \mathrm{~s}^{-1}(\sim 140-180 \mathrm{t}$ $\left.\mathrm{d}^{-1}\right)$, with RMS errors of $\pm 13 \%$ on all values. Our measured $\mathrm{SO}_{2}$ emissions on 4 and 7 June are in the general range reported by the Flame network for the same period (Burton et al., 2015; and available via INGV weekly reports), which measured emission rates of $\sim 130,180$ and $300 \mathrm{t} \mathrm{d}^{-1} \mathrm{SO}_{2}$ on 3, 4 and 7 June, respectively, (no uncertainties given).

Gas molar ratios. The concentrations of major volcanic gas species were measured in the emissions from three distinct vents: N2, C and S1. Data were acquired using an instrumented UAS equipped with a miniaturised Multi-GAS unit (see Methods) during either hovering (N2, S1 and C) or multiple lateral transects through the plume ( $\mathrm{C}$ only). Sections of each timeseries were classified as either passive or explosive degassing based on visual observations made during each flight (Figs. 4 and 5). We find that molar gas ratios during non-explosive passive degassing (or puffing) vary considerably between the different vent areas but are consistent for a specific vent between multiple flights. $\mathrm{H}_{2} \mathrm{~S}$ was not measured above the detection limit during any flight (see Methods). A summary of vent compositions is presented in Table 1 (see also Fig. 6, and Supplementary Figs.).

Overall, calculated molar compositions are distinct for each vent area (Fig. 6). Passive emissions from the central vent area (C) were dominated by water vapour (94-95 mol\%) with $<3 \%$ each of $\mathrm{CO}_{2}$ and $\mathrm{SO}_{2}$. In contrast, the vent area $\mathrm{N} 2$ was associated with a passive gas composition much richer in $\mathrm{CO}_{2}(34-37 \mathrm{~mol} \%)$ and correspondingly reduced in $\mathrm{H}_{2} \mathrm{O}$ (61-63 mol\%). Emissions of $\mathrm{CO}_{2}$ and $\mathrm{H}_{2} \mathrm{O}$ from the southern vent area ( $\left.\mathrm{S} 1\right)$ were found to be intermediate between the two end members. Interestingly, the relative molar proportion of $\mathrm{SO}_{2}$ remained relatively constant (2.7-3.3 mol\%) between all vent areas.

Vent proximal measurements were also acquired during Strombolian explosions, allowing direct comparison of the gas composition emitted during both passive and explosive degassing styles, and the transition between the two states (Fig. 5). Two explosions from N2 were intercepted from a measurement position approximately ten metres above the rim of the vent crater. The northerly wind direction at the time means we cannot exclude a passive degassing contribution from N1; however, the colocated UV camera indicated that $\mathrm{N} 1$ was releasing negligible passive emissions and so any signal would have been dwarfed by the explosive release from N2 (see section 2.2). The onset of each explosion was accompanied by an abrupt increase in the concentration of all gas species by a factor of 4-5 (see Fig. 5). Furthermore, in both cases the molar composition of the emitted vapour phase evolved to a more $\mathrm{CO}_{2}$-rich composition (up to 54 mol\%) relative to the passive emissions measured immediately prior to or following the explosion. $\mathrm{CO}_{2} / \mathrm{SO}_{2}$ increased to 15.3-18.8 ( $\pm 1-2)$ during explosive degassing (Table 1); however, the relative molar proportion of $\mathrm{SO}_{2}$ remained largely unchanged at $2.3-3.5 \mathrm{~mol} \%$ due to the coincident reduction in $\mathrm{H}_{2} \mathrm{O} / \mathrm{SO}_{2}$. Interestingly, in the $20 \mathrm{~s}$ prior to the explosion intercepted during 


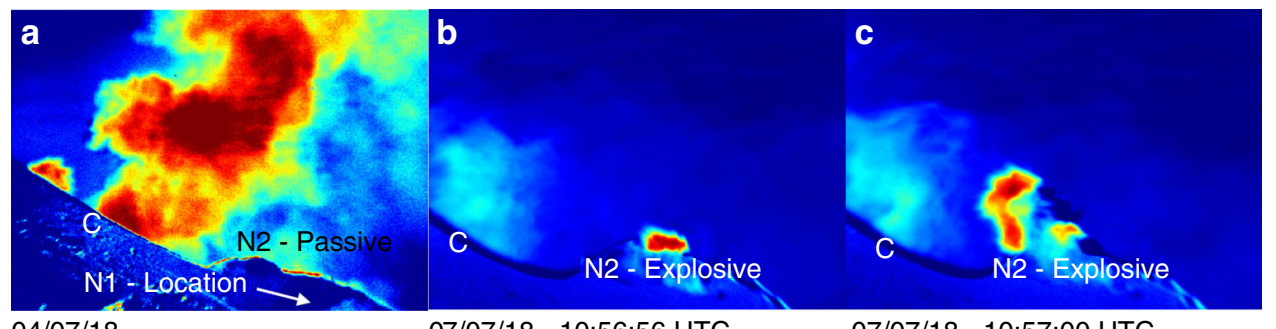

$04 / 07 / 18$

07/07/18 - 10:56:56 UTC

07/07/18 - 10:57:00 UTC

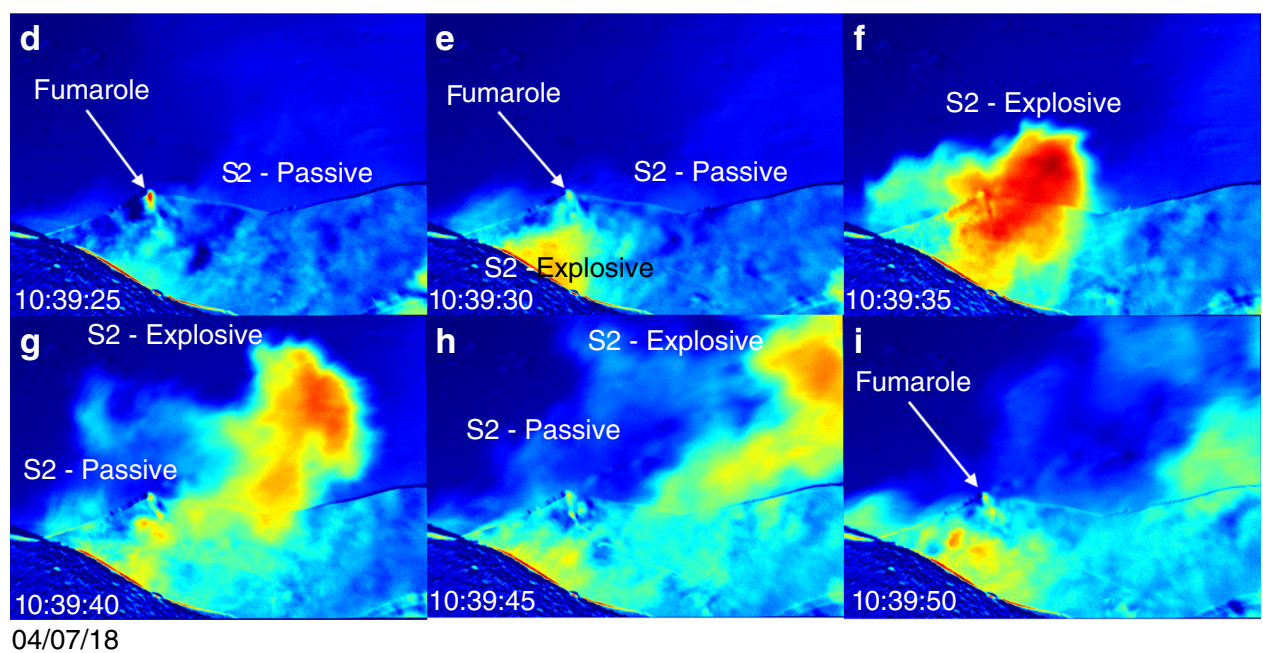

Fig. 2 UV camera absorbance images. Example UV camera absorbance images showing activity from each individual vent imaged. a Data from 04/07/ 18 showing the high contributions of emissions from area C, lack of emissions from N1 and lower contribution to passive degassing from N2; $\mathbf{b}$, c A minor Strombolian explosion from N2 on 07/07/18, as viewed from the north-east; $\mathbf{d}-\mathbf{i}$ An image sequence showing the evolution of a Strombolian explosion from S2, as viewed from the south.

a
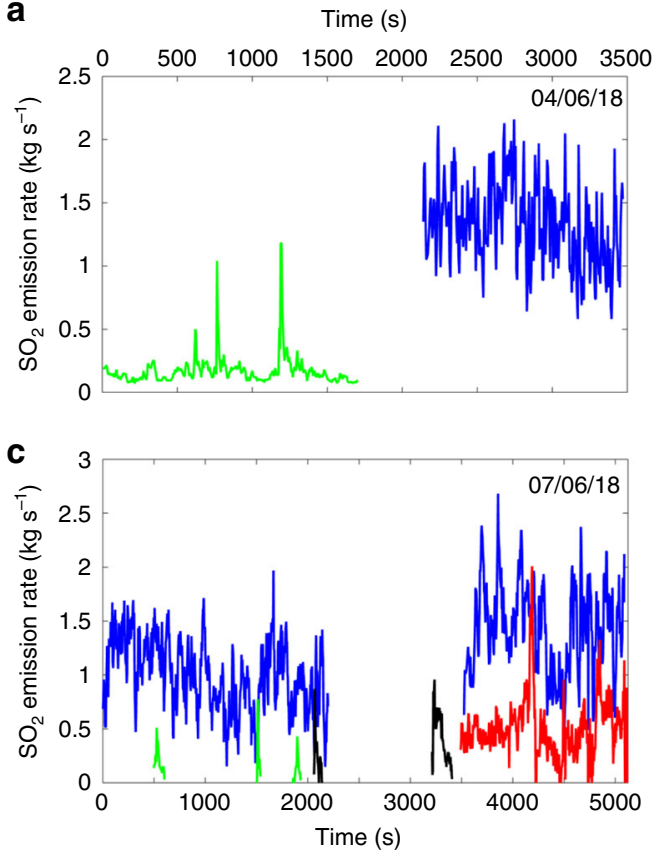

b $\quad \operatorname{Time}(\mathrm{s})$
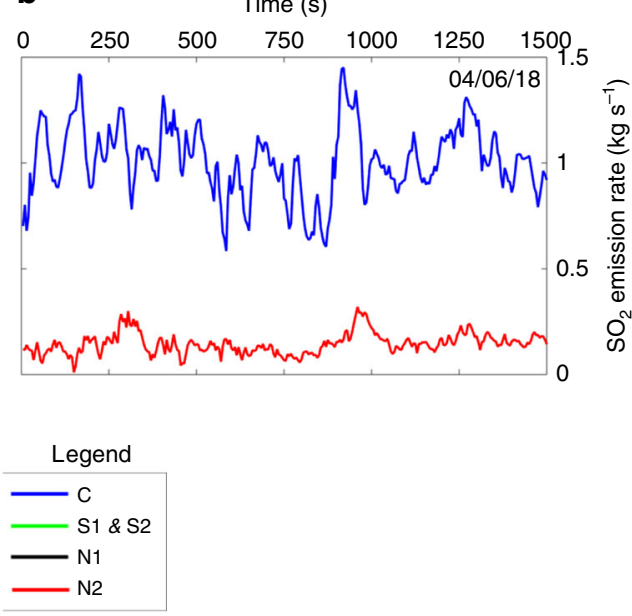

Fig. 3 Vent-specific $\mathbf{S O}_{\mathbf{2}}$ emissions. $\mathrm{SO}_{2}$ emissions from UV camera acquisitions on 04/06/18 and 07/06/18. In a two separate explosions from $\mathrm{S1}$, and elevated emissions from area $\mathrm{C}$; in $\mathbf{b}$ passive emissions from N2 and $\mathrm{C}$ and in $\mathbf{c}$ explosive emissions only from S1, S2 and N1, alongside passive emissions from $C$ and combined passive and explosive emissions from N2. Note the difference in $y$-axis scale between plots. 


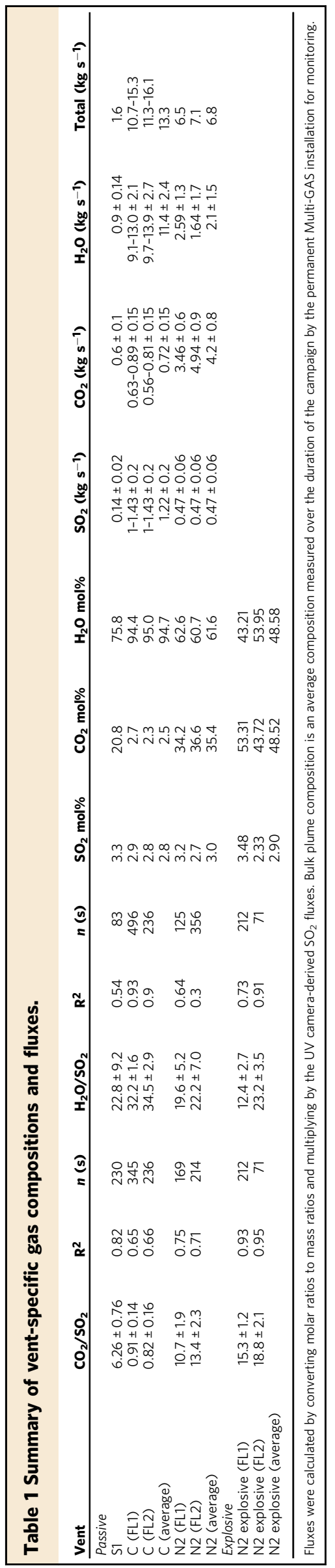

the first flight over N2, the concentration of all gas species dropped to near-background atmospheric levels (see Fig. 5).

\section{Discussion}

By combining vent-specific $\mathrm{SO}_{2}$ emission rates with aerial molar gas ratios measured during passive degassing (and puffing), we have quantified multispecies gas fluxes for each vent area (Table 1). Overall, we estimate that the total outgassing volatile budget from all vent areas is $\sim 21.9 \mathrm{~kg} \mathrm{~s}^{-1}\left(1890 \mathrm{t} \mathrm{d}^{-1}\right)$, of which $\mathrm{SO}_{2}, \mathrm{CO}_{2}$ and $\mathrm{H}_{2} \mathrm{O}$ contribute $\sim 1.8 \mathrm{~kg} \mathrm{~s}^{-1}\left(\sim 160 \mathrm{t} \mathrm{d}^{-1}\right), \sim 5.5 \mathrm{~kg} \mathrm{~s}^{-1}\left(\sim 480 \mathrm{t} \mathrm{d}^{-1}\right)$ and $\sim 14.4 \mathrm{~kg} \mathrm{~s}^{-1}\left(\sim 1240 \mathrm{t} \mathrm{d}^{-1}\right)$, respectively. Of this total, most of the gas ( $\sim 61 \%$ by mass; $\left.\left[\sim 13.3 \mathrm{~kg} \mathrm{~s}^{-1}, \sim 1150 \mathrm{t} \mathrm{d}^{-1}\right]\right)$ is derived from the central vent area, which is predominantly composed of $\mathrm{H}_{2} \mathrm{O}$ $\left(11.4 \mathrm{~kg} \mathrm{~s}^{-1}, 980 \mathrm{t} \mathrm{d}^{-1}\right)$. In contrast, the volatile fluxes from $\mathrm{N}$ and $\mathrm{S}$ vent areas are significantly lower $\left(31 \%\right.$ by mass $\left[\sim 6.8 \mathrm{~kg} \mathrm{~s}^{-1}, \sim 550 \mathrm{t}\right.$ $\left.\mathrm{d}^{-1}\right]$ and $7 \%$ by mass $\left[\sim 1.6 \mathrm{~kg} \mathrm{~s}^{-1}, 140 \mathrm{t} \mathrm{d}^{-1}\right]$, respectively). However, these areas emit proportionally more $\mathrm{CO}_{2}$, with $38 \%$ by mass $\mathrm{CO}_{2}\left(0.6 \mathrm{~kg} \mathrm{~s}^{-1}, 50 \mathrm{t} \mathrm{d}^{-1}\right)$ in the $\mathrm{S}$ vent area, and $73 \%$ by mass $\mathrm{CO}_{2}\left(4.9 \mathrm{~kg} \mathrm{~s}^{-1}, 420 \mathrm{t} \mathrm{d}^{-1}\right)$ in the $\mathrm{N}$ vent area. Note that switching of the locus of Strombolian explosions between vent areas is common, and the central vent area can exhibit more explosive activity than during our observation period $39,42,44$

A key observation from these flux data is that the central vent area is by far the dominant emission source by mass during passive outgassing, despite exhibiting the least explosive behaviour. Sustained puffing activity from multiple vents, combined with visible incandescence, indicates effective gas-melt separation at shallow depths within this vent area. The higher proportions of $\mathrm{CO}_{2}$ combined with markedly lower passive fluxes from $\mathrm{N}$ and $\mathrm{S}$ vent areas are therefore interesting from the perspective of understanding eruption mechanisms, as these are the two craters from which Strombolian explosions place. Our data suggest relatively little open-system gas release between explosions, particularly from $\mathrm{N} 2$, supporting previous suggestions of a rheologically stiffened low permeability cap in the uppermost conduit $48,49,56,58$. If the passive volatile flux can be taken as a proxy for the relative permeability of the shallow conduit between vent areas, this indicates that the central vent area retains high permeability throughout. In contrast, $\mathrm{N}$ and $\mathrm{S}$ vent areas display outgassing behaviours consistent with a variably-degassed crystallisated magma cap that modulates short-timescale rheological variations, with implications for periodic overpressure development. Our results are even more intriguing when it is considered that major explosions most commonly occur from the central vent area $^{59}$, as this highlights that some fundamental change from this background regime must take place prior to or during these large events.

We observe a near-complete cessation in magmatic gas emissions $\sim 20-30$ seconds prior to an explosion (Fig. 5), during which the concentration of $\mathrm{SO}_{2}$ (the plume tracer species) drops to zero. We note that although the excess $\mathrm{H}_{2} \mathrm{O}$ concurrently decreases, it remains slightly elevated at $\sim 400 \mathrm{ppm}$ above background, and we attribute this to the combined effect of natural variability in the ambient background humidity and a slower sensor response. Nevertheless, this abrupt reduction in emissions provides an intriguing indication that more efficient conduit sealing may precede the onset of an explosion, through a rapid reduction in magma permeability ${ }^{60,61}$. Although we cannot exclude the possibility that the UAS moved temporarily out of the plume due to a shift in wind direction during this interval, we did not observe any noticeable meteorological change to this effect in either our line-of-sight observations from the crater rim or in the firstperson camera view from the UAS. Indeed, a similar but less pronounced reduction in emissions was observed prior to a second explosion at N2 (Supplementary Fig. 2). We highlight the 

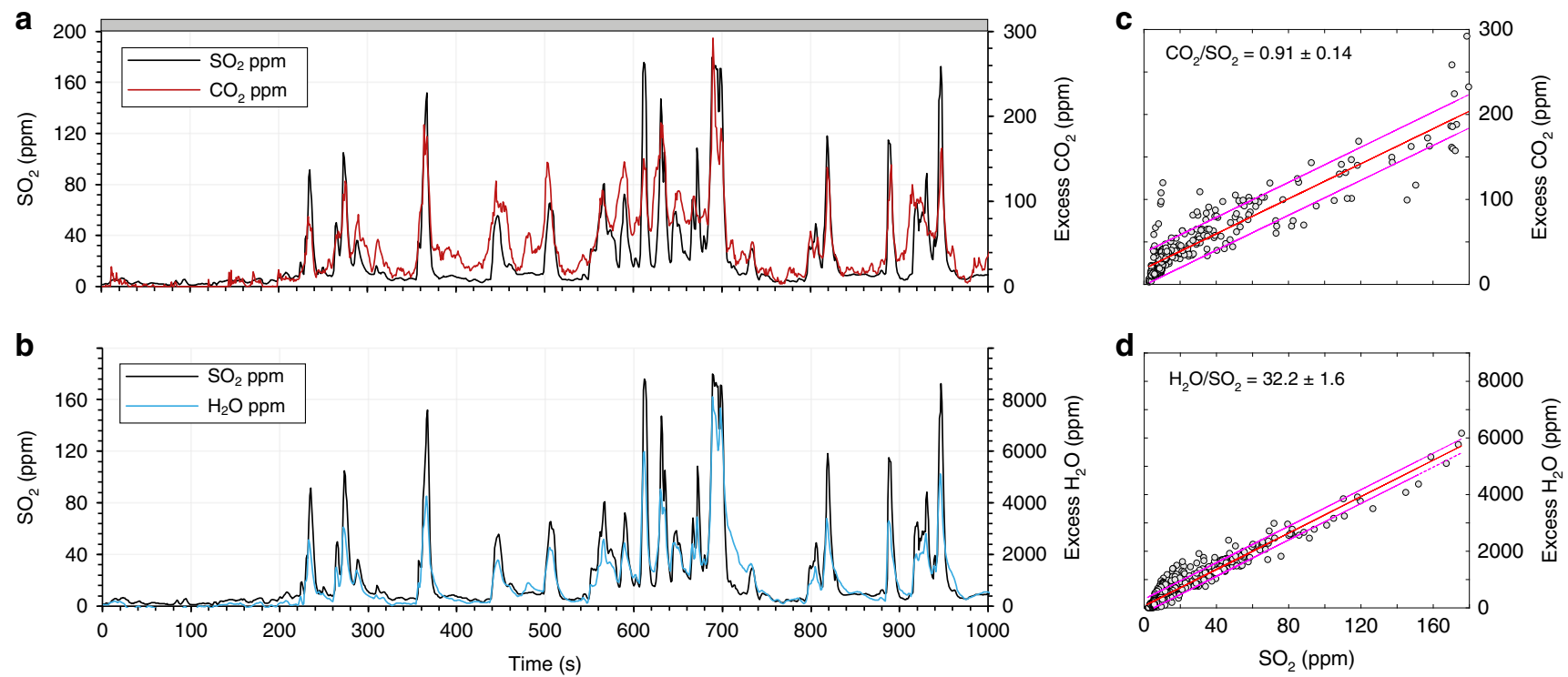

Fig. 4 Molar gas compositions for UAS overflight on 07/06/18. Molar gas composition data for an UAS overflight on 07/06/18 during passive degassing from the central vent area (C), showing gas concentration timeseries for $\mathbf{a} \mathrm{SO}_{2}$ and $\mathrm{CO}_{2}, \mathbf{b ~} \mathrm{SO}_{2}$ and $\mathrm{H}_{2} \mathrm{O}$ and $\mathbf{c}$, $\mathbf{d}$ the corresponding scatterplots, showing the least squares regression and 95\% confidence intervals. Excess refers to the concentration of the gas species of interest above background, which was determined from clean air measurements made outside of the plume where $\mathrm{SO}_{2}=0$. Gas molar ratios correspond to the gradient of the regression line shown. The flight path comprised horizontal transects through the plume around $20 \mathrm{~m}$ downwind of the vent. Each peak indicates passage through the plume, with troughs indicating positions outside of the plume (e.g. where $\mathrm{SO}_{2}$ values $=0$ ).

a

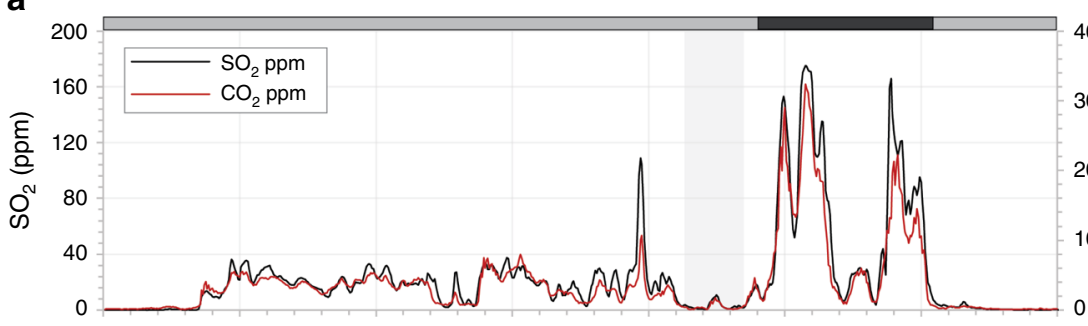

b

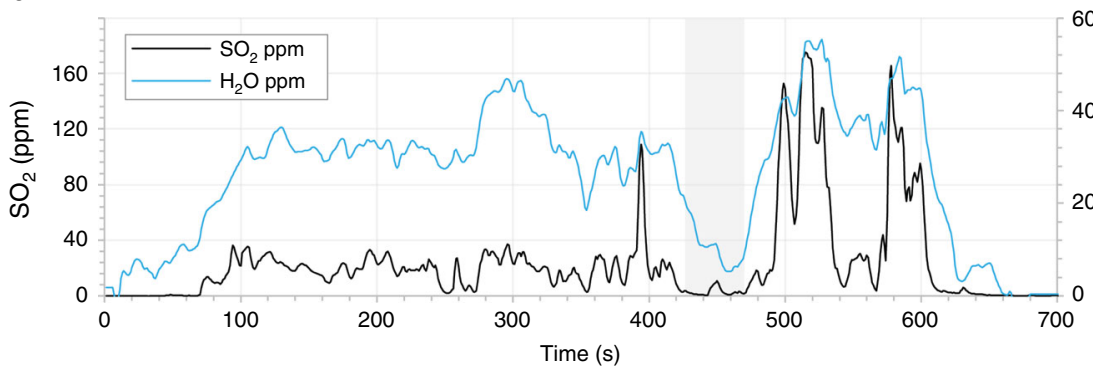

C $\quad \mathrm{CO}_{2} / \mathrm{SO}_{2}=15.3 \pm 1.2$
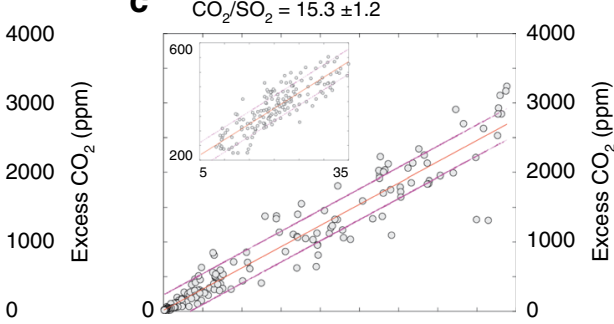

d $\quad \mathrm{H}_{2} \mathrm{O} / \mathrm{SO}_{2}=12.4 \pm 2.7$

6000

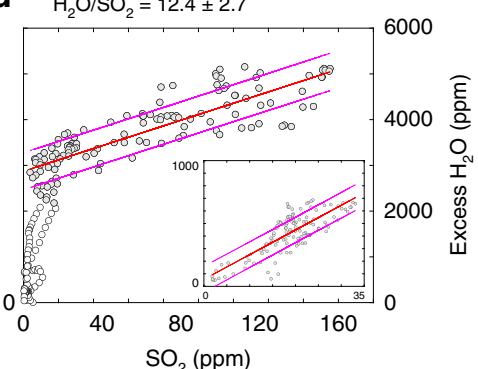

Fig. 5 Molar gas compositions for UAS overflight on 10/06/18. Molar gas composition data for an UAS overflight on 10/06/18 during passive degassing and a Strombolian explosion from vent N2, showing gas concentration timeseries for $\mathbf{a} \mathrm{SO}_{2}$ and $\mathrm{CO}_{2}, \mathbf{b ~} \mathrm{SO}_{2}$ and $\mathrm{H}_{2} \mathrm{O}$. The shaded band at the top indicates passive (grey) and explosive (black) phases. Note the drop in magmatic gas concentrations to background immediately prior to the first explosion (shaded column). c, d Scatterplots for the explosive phase emissions of $\mathrm{SO}_{2}-\mathrm{CO}_{2}$ and $\mathrm{SO}_{2}-\mathrm{H}_{2} \mathrm{O}$, respectively, displaying the least squares regression and $95 \%$ confidence intervals. Excess refers to the concentration of the gas species of interest above background, which was determined from clean air measurements made outside of the plume where $\mathrm{SO}_{2}=0$. Gas molar ratios correspond to the gradient of the regression line shown. Note that for $\mathrm{SO}_{2}-\mathrm{H}_{2} \mathrm{O}$, the regression is only based on $\mathrm{SO}_{2}>10$ ppm due to the highly variable $\mathrm{H}_{2} \mathrm{O}$ at low $\mathrm{SO}_{2}$ concentrations. Inset scatterplots show data for the passive degassing phase. See also Supplementary Fig. 2, for UAS overflight on 10/06/18 during passive degassing and a Strombolian explosion from vent N2.

need for further aerial measurements to explore in more detail this mechanism for passive to explosive transitions.

The molar gas compositions measured in this campaign fall within the ranges of previous studies that differentiated between emissions from distinct vent areas ${ }^{58,62}$, but with some notable differences (Fig. 7). For example, at vent area N, we measured substantially elevated molar proportions of $\mathrm{CO}_{2}$ during nonexplosive degassing than previously described (34-37 mol\% compared to $\left.8-9 \mathrm{~mol} \%{ }^{58}\right)$. Crucially, our results provide further support to the hypothesis that gas emissions during transient 

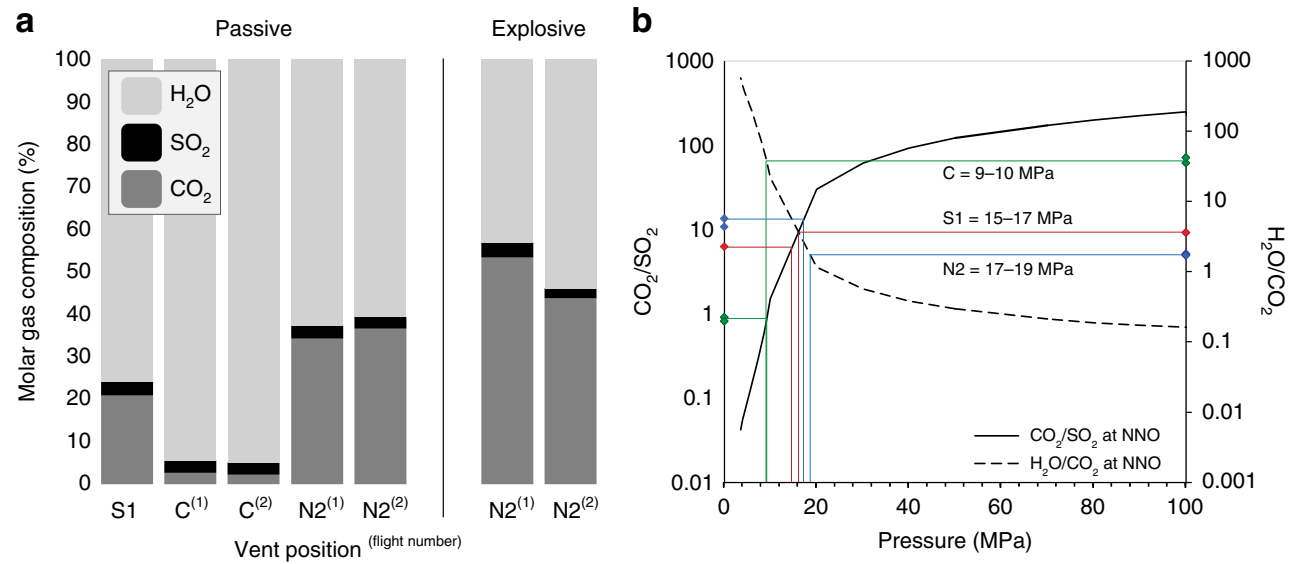

Fig. 6 Vent-specific molar compositions and degassing pressures model. a Summary of vent-specific molar gas compositions during passive and explosive degassing. The elevated $\mathrm{CO}_{2}$ composition of $\mathrm{N} 2$ compared to $\mathrm{C}$ and $\mathrm{S} 1$ is evident. The composition of explosive gas emissions from $\mathrm{N} 2$ indicates elevated $\mathrm{CO}_{2}$ composition relative to the preceding and/or succeeding passive emissions in the same flight. $\mathbf{b}$ Degassing pressures: Measured passive/ non-explosive gas compositions superposed on modelled gas compositions, expressed as $\mathrm{CO}_{2} / \mathrm{SO}_{2}$ (solid line) and $\mathrm{H}_{2} \mathrm{O} / \mathrm{CO}_{2}$ (dashed line) during closed system degassing from 100 to $0.1 \mathrm{MPa}$ buffered at NNO (nickel-nickel oxide redox buffer). See methods for details of model starting composition. Increasing equilibrium pressures (i.e. shallower depths of degassing) are observed from C to S1 to N2.

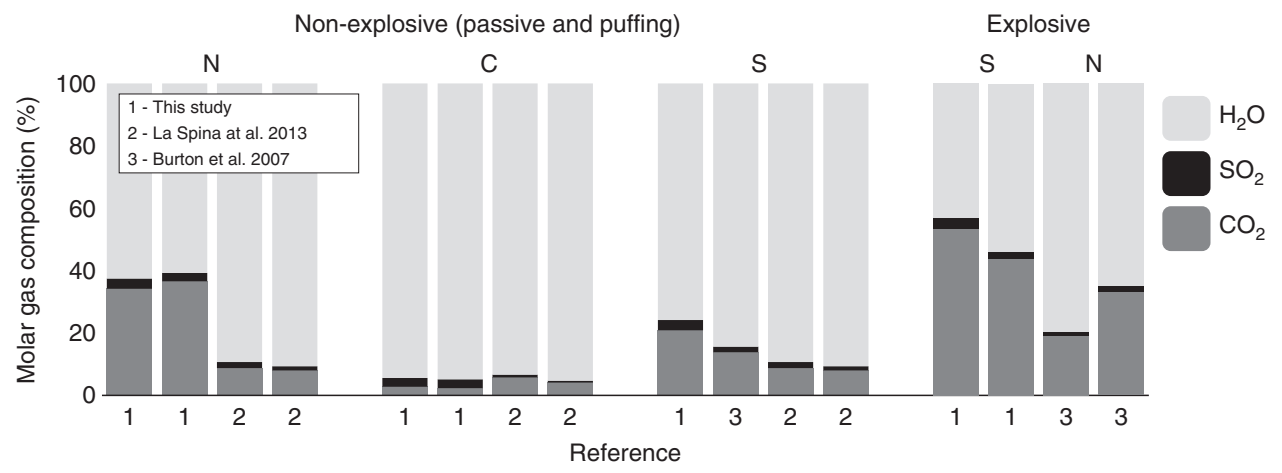

Fig. 7 Comparison of molar gas compositions with previous studies. Comparison of molar gas compositions (mol \%) of major species measured in this study, to previously published data for both non-explosive (passive degassing/puffing) and explosive degassing.

explosions are more $\mathrm{CO}_{2}$-rich than those from continuous passive degassing. We find that that molar proportion of $\mathrm{CO}_{2}$ increases at the northern vent area by $24-50 \mathrm{~mol} \%$ relative to passive emissions, consistent with the lower end of the 40-143 mol\% increase previously documented at the southern vent area $^{62}$. These temporal differences emphasise both the dynamic nature of the volcanic activity at Stromboli, and also the necessity of vent-specific analysis to track spatial heterogeneity through time. However, the reproducibility of these passive-explosive characteristics lends great support to process-based models of Strombolian explosions built around the principle of deeply sourced $\mathrm{CO}_{2}$-rich gas ${ }^{63}$.

The gas-melt partitioning behaviour of major magmatic volatile species is strongly pressure-dependent, and so the composition of the vapour phases can be related thermodynamically to the pressure (i.e. depth) of gas-melt segregation and final equilibration $2,5,13,62$. The equilibrium gas composition of surface emissions can therefore be simulated based on thermodynamic models of volatile solubility, calibrated on experimental data ${ }^{2-4,6}$. Here, we simulate the evolution in gas composition as a function of pressure from 100 to $0.1 \mathrm{MPa}$ under conditions of closed system degassing using the model presented by Moretti and Papale 4 . From a shoshonitic (potassic, iron-poor and near silicasaturated ${ }^{64}$ ); starting melt composition (based on melt inclusion compositions from Métrich et al. $^{65}$ and the same initial conditions as Aiuppa et al. $^{8}$ ) and buffered redox conditions of either NNO (where NNO refers to the nickel-nickel oxide redox buffer), we compare our aerial measurements to modelled $\mathrm{CO}_{2}$ / $\mathrm{SO}_{2}$ and $\mathrm{H}_{2} \mathrm{O} / \mathrm{CO}_{2}$ ratios in the gas phase in order to estimate the pressure of gas-melt segregation (Fig. 6b). Full details of the model are presented by Aiuppa et al. ${ }^{8}$.

Figure $6 \mathrm{~b}$ illustrates how the pressure of gas-melt equilibration (i.e. depth of degassing), under closed-system conditions, increases from $\mathrm{C}$ to $\mathrm{S} 1$ to $\mathrm{N} 2$. While active 'puffing' emissions from the central vent area (C) reflect relatively low pressure degassing of $\sim 9 \mathrm{MPa}$, the higher $\mathrm{CO}_{2} / \mathrm{SO}_{2}$ ratios characteristic of the southern $(\mathrm{S} 1)$ and northern $(\mathrm{N} 2)$ vent areas are consistent with greater equilibration pressures $\left(\mathrm{P}_{\text {eq }}\right)$ of 15-17 and 17-19 $\mathrm{MPa}$, respectively. Under a lithostatic pressure gradient, these $\mathrm{P}_{\mathrm{eq}}$ correspond to approximate depths of $\sim 330 \mathrm{~m}$ (C), $\sim 550-625 \mathrm{~m}$ (S1), and $\sim 625-700 \mathrm{~m}$ (N2) beneath the surface. When the uncertainties on the molar gas ratios are considered, $\mathrm{P}_{\mathrm{eq}}$ ranges overlap for S1 and N2 and therefore they cannot be resolved fully. We also note that these depths are underestimates for the case of an established conduit, and that a magmastatic pressure gradient (assuming the density of vesicular magma to be $1.5 \mathrm{~g} \mathrm{~cm}^{-3}$ ) yielding $\sim 600 \mathrm{~m} \mathrm{(C),} \sim 1000-1150 \mathrm{~m}$ (S1) and $\sim 1150-1300 \mathrm{~m}$ (N2) may be a more appropriate upper bound. Explosions from $\mathrm{N} 2$ reflect yet further elevated degassing pressures of $19-24 \mathrm{MPa}$, which are at the lower limit of the $20-50 \mathrm{MPa}$ range for 'small 
explosions' proposed in previous literature, consistent with visual observations of explosion magnitude ${ }^{62}$. We note that the choice of solubility model, starting melt composition and redox condition has a large effect on the absolute equilibration pressure, therefore we urge caution against over-interpreting absolute pressures. Nevertheless, we consider the relative differences in depth of gas-melt separation between vents to be robust. Together, these data suggest that the depth of final gas-melt equilibration is most shallow in the central vent area (more $\mathrm{H}_{2} \mathrm{O}$-rich emissions), and deeper in the $\mathrm{N}$ and $\mathrm{S}$ vent areas (more $\mathrm{CO}_{2}$-rich emissions). Alternatively, if we interpret our data in the context of multiple gas sources ${ }^{8,32}$, then the different gas ratios measured at the surface instead populate a mixing trend between a deep $\mathrm{CO}_{2}$ rich vapour phase and $\mathrm{SO}_{2}$ - and $\mathrm{H}_{2} \mathrm{O}$-rich vapours derived from degassing within the shallow conduit system. The elevated $\mathrm{CO}_{2} /$ $\mathrm{SO}_{2}$ ratios measured at $\mathrm{S} 1$ and $\mathrm{N} 2$ would then imply a greater connection to the deeper gas source, with little re-equilibration during low pressure ascent through the shallow magmatic system as a segregated vapour phase. In contrast, puffing from the central vent area would be driven predominantly by low pressure degassing from magma within a shallow reservoir, consistent with previous data indicating an $\mathrm{H}_{2} \mathrm{O}$-rich gas composition ${ }^{32}$ and elevated magma temperatures 39 .

Combining modelled equilibration pressures with vent-specific gas fluxes, we propose a conceptual model to explain the link between the observed outgassing dynamics and the subsurface plumbing system. At the central vent area, the stable 'puffing' activity and elevated volatile fluxes (relative to other vent areas) during passive emissions require that the shallow conduit remains highly permeable to gas escape. Further, solubility constraints show that the sustained gas supply required to maintain the observed outgassing rates must derive from low pressure degassing, which is best explained by late-stage gas-melt separation during shallow magma convection. If indeed the main 'branch' of the subsurface conduit system lies beneath central vent area, as previously suggested ${ }^{39}$, elevated magma temperature may provide an important feedback that inhibits crystallisation and thus maintains permeability ${ }^{32}$ aided by increased throughput of higher volumes of gas. In contrast, the modest to negligible passive fluxes from $\mathrm{N}$ and $\mathrm{S}$ vent areas between Strombolian explosions suggest reduced permeability in the shallow conduits. Together with more $\mathrm{CO}_{2}$-rich passive emissions (compared to central vent area), these observations point to a deeper gas-melt separation and a lack of shallow magma replenishment. In the context of a branched conduit system, lateral vents with reduced flow, and thus lower magma temperatures, can develop plug-like rheologies. The proposed rheological contrast between $\mathrm{C}$ and $\mathrm{N}+\mathrm{S}$ vent areas can explain the spatial distribution of explosive activity as, according to the crystal-rich plug models for Strombolian explosions ${ }^{48}$, rheological factors such as reduced permeability and increased bulk viscosity are critical to overpressure. Further, the greater saturation pressures calculated for explosive emissions are consistent with those studies advocating for a deep origin for the gas slugs that drive Strombolian activity ${ }^{62}$.

Ground-based multi-GAS measurements from the permanent monitoring station on the crater $\operatorname{rim}^{8,12}$ during 4-11 June 2018, highlight the temporal variability of bulk plume compositions (Fig. 8, and Supplementary Fig. 4). $\mathrm{CO}_{2} / \mathrm{SO}_{2}$ (molar) during passive degassing, defined as persistent activity measured over tens of minutes, spanned 2.1-7.8 with a stable average composition of $3.9 \pm 1.4(\sigma)$. These molar ratios are intermediate between our measured values for C, S2 and N2 vent areas, demonstrating that variable amounts of plume mixing must occur during transport to the crater rim. Passive emissions measured on the crater rim are therefore 'bulk' plume measurements. $\mathrm{CO}_{2} / \mathrm{SO}_{2}$ molar ratios during explosive degassing, defined as transient peaks in the timeseries lasting $<60 \mathrm{~s}$, span $6.8-25.4$ with an average composition of $14.0 \pm 4.35(\sigma)$. This composition is in good agreement with the elevated ratios $\left(\mathrm{CO}_{2} / \mathrm{SO}_{2}=15.3 \pm 1.2\right.$ and $18.8 \pm 2.1)$ derived from aerial measurements during explosive activity at $\mathrm{N} 2$ (Fig. 5). The more $\mathrm{CO}_{2}$-rich compositions in the monitoring timeseries (up to $\mathrm{CO}_{2} / \mathrm{SO}_{2}=25$ ) may derive from explosive exhalations from $\mathrm{N} 1$, which at the time of our measurements was exhibiting significantly more energetic Strombolian explosions than $\mathrm{N} 2$ and therefore could not be characterised safely using the UAS. $\mathrm{CO}_{2} / \mathrm{SO}_{2}$ has been shown to scale with explosion magnitude ${ }^{62}$.

The challenges of using a single Multi-GAS station in a multivent context are highlighted by Fig. 8. Calculated ratios are hybridized values based on contributions from multiple vents and contrasting degassing styles, but this value is strongly dependent on the prevailing wind direction as this determines the nature of plume mixing ${ }^{58}$. For example, the wind direction on 7 June was westerly, resulting in strong passive contributions from $\mathrm{C}$ and $\mathrm{S} 1$ and a low average $\mathrm{CO}_{2} / \mathrm{SO}_{2}$ ratio of $2.9 \pm 0.6$. In comparison, the south-easterly wind on 8 June meant that passive degassing was generally below detection and only strong explosive emissions reached the station, yielding a high average $\mathrm{CO}_{2} / \mathrm{SO}_{2}$ of $14.6 \pm 1.7$. Bulk plume molar proportions of $48-98$ mol\% (mean, $80 \%$ ), 2-50 $\mathrm{mol} \%$ (mean, $17 \%$ ) and $0.2-14 \mathrm{~mol} \%$ (mean, $3 \%$ ) have been presented previously for $\mathrm{H}_{2} \mathrm{O}, \mathrm{CO}_{2}$ and $\mathrm{SO}_{2}$, respectively ${ }^{8}$. Our data, based on vent-specific measurements, are within the quoted ranges for all vents; however, we emphasise that the bulk composition is not wholly representative of degassing at any single vent. Distinguishing between differences in the relative contributions of distinct vent-specific emissions from true changes in the subsurface conditions of degassing is critical to the use of gas measurements as a robust monitoring parameter.

We show, using a novel approach combining ground-based $\mathrm{UV}$ remote sensing of $\mathrm{SO}_{2}$ flux with vent-specific aerial measurements of gas composition, that volcanic gas emissions at Stromboli are spatially heterogeneous in both chemistry and emission rate between distinct vent areas. The central vent area (C) contributed $61 \%$ of the total emissions, and therefore dominated the emissions budget. Emissions from vent area $\mathrm{C}$ were non-explosive, $\mathrm{H}_{2} \mathrm{O}$-rich, characterised by $95 \mathrm{~mol} \% \mathrm{H}_{2} \mathrm{O}$ and $\mathrm{H}_{2} \mathrm{O} / \mathrm{SO}_{2}$ ratios of $32-35$, and associated with puffing. Contrastingly, the southern $(\mathrm{S})$ and northern $(\mathrm{N})$ vent areas exhibited frequent Strombolian explosions, with passive emissions characterised by greater proportions of $\mathrm{CO}_{2}(35 \mathrm{~mol} \%)$ and lower overall volatile fluxes. To explain our observations and modelled degassing depths (shallowing from $\mathrm{C}$ to $\mathrm{S} 1$ to $\mathrm{N} 2$ ), we propose a conceptual model whereby the gas-rich central vent area is sustained by shallow convection and associated late-stage separation between gas and melt, which maintains a high permeability in the shallow conduit. In contrast, the gas-poor but proportionally $\mathrm{CO}_{2}$ rich $\mathrm{S}$ and $\mathrm{N}$ vent areas show evidence for reduced permeability to a deeply sourced gas, a condition that would favour the formation of a crystal-rich plug and thus promote Strombolian activity. By comparing vent-specific measurements to bulk plume' estimates from a permanent monitoring installation, we highlight that variable degrees of plume mixing during transport to the crater rim generate bulk plume signatures that are intermediate between the molar compositions characteristic of the distinct vent areas. Therefore, sub-daily to daily variations in $\mathrm{CO}_{2} / \mathrm{SO}_{2}$ may result simply from changes in the relative contribution of different vents (e.g. by a change of wind direction). This spatial heterogeneity has implications for the interpretation of monitoring data based on bulk plume measurements and emphasises the need for a vent-specific approach, using our novel combined approach, at multi-vent volcanoes to understand further the links between degassing and eruptive style. 


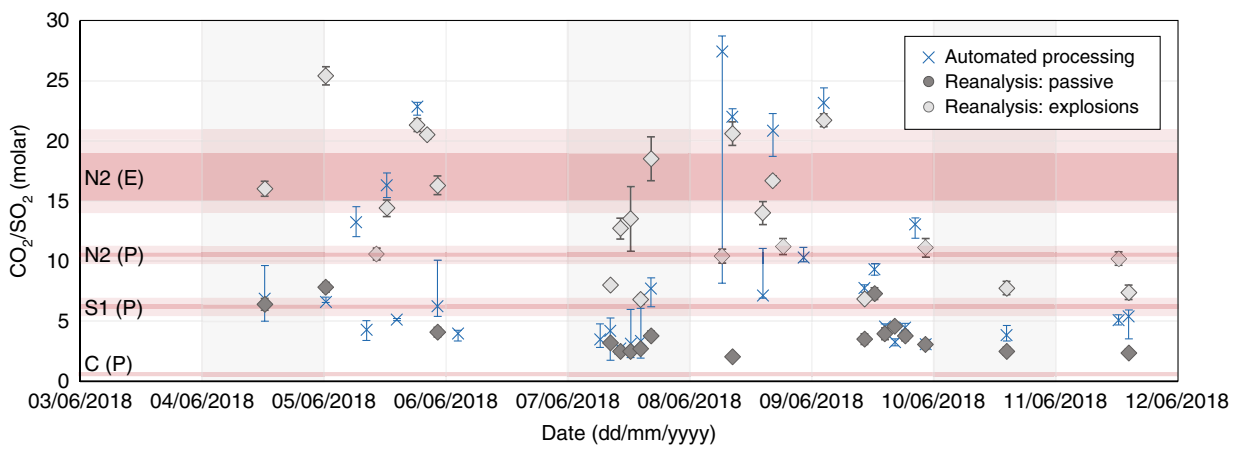

Fig. 8 A comparison of ground based on UAS $\mathbf{C O}_{2} / \mathbf{S O}_{\mathbf{2}}$ molar ratios. Ground-based multi-GAS measurements from the permanent monitoring station located on the crater rim of Stromboli. Timeseries of $\mathrm{CO}_{2} / \mathrm{SO}_{2}$ molar gas ratios measured 4-11 June 2018, showing automatically processed (blue crosses) and reanalysed (grey symbols) ratios. Passive degassing (dark grey symbols) represents persistent activity measured over tens of minutes, while explosive degassing (light grey symbols) represents transient peaks lasting $<60 \mathrm{~s}$. Red shaded bars correspond the aerial vent-specific gas compositions and $95 \%$ confidence intervals presented in Table 1 for passive (P) and explosive (E) emissions.

\section{Methods}

Ultraviolet camera. UV camera data were collected using the low-cost 'PiCam' on $04 / 06 / 18$ and $07 / 06 / 18$, totalling $\sim 50 \mathrm{~min}$ on $04 / 06 / 18$ and $\sim 3 \mathrm{~h}$ on $07 / 06 / 18$. Here, we used a modified system setup to that described in Wilkes et al., 2017, 2016 25,66 , by incorporating 'PiJuice' hardware and software (https://github.com/PiSupply/ Pijuice) we were able to reduce the dimensions of the equipment, significantly increasing portability and potential for long-term remote placement. The PiJuice is an add-on for the Raspberry Pi micro-computer (https://www.raspberrypi.org/), which enables uninterruptible power supply to the Raspberry Pi via mobile phone batteries (we tested $1600 \mathrm{mAh}$ and $2300 \mathrm{mAh}$ batteries), which were recharged inthe-field using $40 \mathrm{~W}$ solar panels, i.e. one Pijuice and $40 \mathrm{~W}$ solar panel for each Raspberry Pi (see Supplementary Fig. 5). On their own, the phone batteries 2300 $\mathrm{mAh}$ batteries provided $\sim 2 \mathrm{~h}$ of acquisition time. Each camera also incorporated a visible camera, attached to the 'Raspberry Pi Zero' micro-computer, which was powered using the GPIO (General Purpose Input/Output) pins of one of the PiJuice units, with colour image stills captured every second. This setup, with sufficient solar exposure, allowed the continued use of the cameras without the need for a USB power bank as per refs. ${ }^{25,66}$.

Cameras were deployed around the summit area (see Supplementary Fig. 5), to enable the isolation of $\mathrm{SO}_{2}$ emission rates from each vent (see Fig. 4). Each camera had two Edmund Optics Inc. filters, centred at 310 and $330 \mathrm{~nm}$, which account for where $\mathrm{SO}_{2}$ does and does not absorb, respectively. These filters had full width at half maximum of $10 \mathrm{~nm}$. Images were captured at acquisition rates of $0.2-0.25 \mathrm{~Hz}$, dependent on light conditions, and UTC GPS time-stamped. After acquisition, images were aligned, and dark and clear image corrected to account for the effects of sensor noise and vignetting respectively. Using the Beer-Lambert law pixel intensities were converted to column amounts using gas calibration cells (205, $1022,1960 \mathrm{ppm} \mathrm{m}$; with manufacturer quoted errors of $~ 10 \%)$. At certain camera locations, gas cell calibration was performed using a uniform ocean background, producing acceptable calibration lines $\left(\mathrm{R}^{2}>0.98\right.$ in each instance), elsewhere, clear sky was used.

Plume speeds were high $\left(>4 \mathrm{~m} \mathrm{~s}^{-1}\right)$, therefore cross-correlation was used as optical flow did not efficiently track individual pulses of gas given proximity to the plume, see Fig. 4d-i. In addition, light conditions did not allow faster camera acquisition rates. $\mathrm{SO}_{2}$ emission rates were then determined through multiplication of plume speed by integrated column amounts (ICA) along a defined line in each image. Each ICA was chosen to isolate individual vent emissions, and were also used to remove the emissions of one vent from others, when plumes from two sources combined. All camera locations are provided in supplementary Fig. 5.

Overall, root-mean-square errors are estimated at $\sim 13 \%$. These are based on: low-light dilution effect given proximity to plume $\sim 20 \%$, with the lower of the $20-80 \%$ indicated by ref. ${ }^{67}$ used here; the plume was not optically thick, ergo deviation from the Beer-Lambert law were deemed to be low; ${ }^{68}$ plume speed errors of $\pm 10 \%{ }^{69,70}$; manufacturer quoted $\sim 10 \%$ errors in gas calibration cells; and finally error associated with distance to the plume. The latter error was minimised through use of UAS data, which pinpointed plume direction and hence position at integration line, and through manual estimates of plume direction in-the-field and within the UV camera imagery. We estimate that our inference of plume distance, based on the above estimates, are therefore low, however, a deviation of $\pm 20 \mathrm{~m}$, could lead to errors of $10 \%$ in $\mathrm{SO}_{2}$ flus values at a distance of $\sim 300 \mathrm{~m}$, we therefore also incorporate this error. For full details on UV camera procedures please see, for example ${ }^{71-73}$

Multi-GAS. Concentrations of $\mathrm{CO}_{2}, \mathrm{SO}_{2}$ and $\mathrm{H}_{2} \mathrm{~S}$ were measured at $1 \mathrm{~Hz}$ within the volcanic plume using a miniaturised multi-component gas analyser (Multi$\mathrm{GAS}^{7,30,74}$ ), flown on a multirotor Unoccupied Aerial System (UAS). $\mathrm{SO}_{2}$ and $\mathrm{H}_{2} \mathrm{~S}$ electrochemical sensors (T3ST/F-TD2G-1A and T3H-TC4E-1A, both City
Technology) are calibrated for 0-200 and 0-50 ppmv, respectively, both with an accuracy of $\pm 2 \%$ and a resolution of $0.1 \mathrm{ppmv}$. The nondispersive infrared (NDIR) $\mathrm{CO}_{2}$ spectrometer (Microsensorik Smartgas Modul Premium2) is calibrated for 0-3000 ppmv with an accuracy of $\pm 2 \%$ and a resolution of 1 ppmv. The $\mathrm{CO}_{2}$ spectrometer unit was wrapped in brass foil to shield the sensor board from radio frequency interference from the UAS transmission system. Pressure $( \pm 1 \mathrm{hPa})$, temperature $\left( \pm 0.5^{\circ} \mathrm{C}\right)$ and relative humidity $( \pm 3 \%)$ were measured at $1 \mathrm{~Hz}$ using a Bluedot BME280 sensor. $\mathrm{H}_{2} \mathrm{O}$ concentrations were calculated according to Arden Buck equations (relating the pressure of vapour saturation to temperature for moist air; Buck, 1981) from records of temperature and relative humidity measured onboard the UAS, using a time-averaged ambient pressure of $925 \mathrm{mbar}$. Air was sampled through a $1 \mu \mathrm{m}$ particle filter exposed to ambient air, at pump rate of $1.0 \mathrm{~L} / \mathrm{min}$. The multi-GAS was calibrated with standard references gases at the Università di Palermo one week prior to the field campaign, and again 2 weeks after. No significant sensor drift requiring data correction was identified. All sensor data were logged on-board to a micro-SD card, and also telemetered directly to the ground station where it could be visualised in real-time.

A second prototype gas sensor unit, the Aeris (Airgraph, Australia), was flown for a single flight over vent $\mathrm{S} . \mathrm{SO}_{2}$ (electrochemical) and $\mathrm{CO}_{2}$ (NDIR spectrometer) concentrations (together with pressure, temperature and relative humidity) were measured at a $1.25 \mathrm{~Hz}$ sampling rate with a repeatability of $\pm 2 \%$ for both gas species ${ }^{30}$.

Gas concentration timeseries from both sensors were post-processed using MATLAB routines and Ratiocalc software ${ }^{75} \cdot \mathrm{CO}_{2}$ concentrations were corrected for temperature $( \pm 0.2 \%$ full span per degree Celsius; internal compensation) and pressure $\left( \pm 0.15 \%\right.$ per $\mathrm{hPa}$ ). $\mathrm{SO}_{2}$ and $\mathrm{H}_{2} \mathrm{~S}$ concentrations were corrected for reduced ambient pressure at altitude using the manufacturer-stated compensation of $0.015 \%$ and $0.008 \%$ signal per mbar, respectively. Nevertheless, barometric pressure varied by $<2$ mbar over the duration of the flights, as the UAS was flown at near constant altitude. Volcanogenic $\mathrm{CO}_{2}$ was resolved from atmospheric background by subtracting the $\mathrm{CO}_{2}$ concentration in ambient air (measured outside the plume where $\mathrm{SO}_{2}=0$ ) from the raw $\mathrm{CO}_{2}$ timeseries. In our measurements, $\mathrm{H}_{2} \mathrm{~S}$ is correlated with $\mathrm{SO}_{2}$ at $\mathrm{H}_{2} \mathrm{~S}_{/} \mathrm{SO}_{2}=0.1$, which is within the laboratory-determined cross-sensitivity of $\mathrm{H}_{2} \mathrm{~S}$ to $\mathrm{SO}_{2}$ (13\%; using standard reference gases); $\mathrm{H}_{2} \mathrm{~S}$ is therefore considered to be below the detection limit. $\mathrm{H}_{2} \mathrm{O}$ exhibited the greatest temporal variability and regression uncertainties, due to varying meteorological conditions during the measurement period.

Differences in sensor response characteristics were accounted for using a deconvolution algorithm applied to the $\mathrm{CO}_{2}$ timeseries (Supplementary Fig. 1). The algorithm is initiated using the measured timeseries and makes use of a sensor model determined empirically from the response of the nondispersive infrared (NDIR) spectrometer to step changes in calibration gas concentration. The sensor model is best described by a windowed integral and can be thought of as an $\mathrm{N}$ point moving average applied to the 'true' input signal. Laboratory tests identified the sensor to average over $\sim 15$ seconds, hence $N=15$ since measurements are stored at $1 \mathrm{~Hz}$. The deconvolution has the effect of removing the inherent filtering effect of the sensor, hence the recovered input signal shows peaks in concentration that are steeper, narrower and often greater in amplitude than the measured signal.

Molar ratios $\left(\mathrm{CO}_{2} / \mathrm{SO}_{2}, \mathrm{H}_{2} \mathrm{O} / \mathrm{CO}_{2}\right.$ and $\left.\mathrm{CO}_{2} / \mathrm{H}_{2} \mathrm{O}\right)$ were derived from gas-gas scatterplots by calculating the gradient of the best-fit linear regression line through the data. Datapoints where $\mathrm{SO}_{2}$ is present at $<5$ ppmv were excluded from the regression due to the greater error associated with very dilute plumes (e.g. Aiuppa et al., 2009). Uncertainties in derived molar gas ratios are $\geq 6.4 \%$ at $>10 \mathrm{ppm} \mathrm{SO}_{2}$ level and $12.5 \%$ at $<10 \mathrm{ppm} \mathrm{SO}_{2}$, based on the results of laboratory tests and sensor response forward modelling ${ }^{30}$. Uncertainties on derived $\mathrm{CO}_{2}$ and $\mathrm{H}_{2} \mathrm{O}$ volatile fluxes are based on the propagation of errors from both the molar gas ratios and the UV camera-derived $\mathrm{SO}_{2}$ flux timeseries, assuming a conservative uncertainty on the molar ratio at $\pm 12 \%$. 
Unoccupied aerial system (UAS) methods. The aerial multi-GAS was flown onboard a custom-built octocopter in the X8 configuration based on a Vulcan 'Black Widow' frame with hub-to-hub diameter of $120 \mathrm{~cm}$ (Vulcan UAV, UK). This UAS platform is described in detail by Liu et al. ${ }^{30}$ and in the accompanying supplementary information (Supplementary Fig. 3). Transmitted live data included information on the vehicle status, such as battery voltage and altitude, and realtime gas concentrations from the aerial multi-GAS sensor. The Aeris sensor (Airgraph, Australia) was flown on a DJI Phantom 3 quadcopter customised with a long-range transmission unit. The complete sensor package (including sensors, pump, tubing, outer casing and wireless telemetry unit) has a mass of $\sim 300 \mathrm{~g}$ and has been designed specifically to integrate with the Phantom series by clipping to the struts beneath the camera gimbal as a removable modular unit ${ }^{30}$.

The UAS were flown from two locations in the summit area: Fortini on 07/06/ 2018 to access the $C$ and S vent areas, and La Rochetta on 10/06/2018 to access the $\mathrm{N}$ vent area. The total duration of each flight was $15-17 \mathrm{~min}$, of which $~ 70-80 \%$ of that time was spent within the plume. The UAS were positioned to either hover in a static position directly over each vent, or traverse through the plume a few tens of metres downwind, in order to ensure as far as possible that vent-specific emissions were measured with minimal contributions from neighbouring vents. Visual Line of Sight (VLOS) to the UAS was maintained at all times. Flight details, including target vents, are presented in Supplementary Table 1.

\section{Data availability}

The data are available upon reasonable request from the authors.

Received: 18 November 2019; Accepted: 26 May 2020;

Published online: 16 June 2020

\section{References}

1. Sparks, R. S. J. The dynamics of bubble formation and growth in magmas: a review and analysis. J. Volcanol. Geotherm. Res. 3, 1-37 (1978).

2. Dixon, J. E., Clague, D. A., Wallace, P. \& Poreda, R. Volatiles in alkalic basalts from the North Arch volcanic field, Hawaii: Extensive degassing of deep submarine-erupted alkalic series lavas. J. Petrol. 38, 911-939 (1997).

3. Papale, $\mathrm{P}$. Modeling of the solubility of a one-component $\mathrm{H}_{2} \mathrm{O}$ or $\mathrm{CO}_{2}$ fluid in silicate liquids. Contrib. Mineral. Petrol. 126, 237-251 (1997).

4. Moretti, R. \& Papale, P. On the oxidation state and volatile behavior in multicomponent gas-melt equilibria. Chem. Geol. 213, 265-280 (2004).

5. Edmonds, M. New geochemical insights into volcanic degassing. Philos. Trans. R. Soc. A Math. Phys. Eng. Sci. 366, 4559-4579 (2008).

6. Witham, F. et al. SolEx: A model for mixed COHSCl-volatile solubilities and exsolved gas compositions in basalt. Comput. Geosci. 45, 87-97 (2012).

7. Shinohara, H. A new technique to estimate volcanic gas composition: plume measurements with a portable multi-sensor system. J. Volcanol. Geotherm. Res. 143, 319-333 (2005)

8. Aiuppa, A. et al. A model of degassing for Stromboli volcano. Earth Planet. Sci. Lett. 295, 195-204 (2010).

9. Werner, C. et al. Deep magmatic degassing versus scrubbing: elevated $\mathrm{CO}_{2}$ emissions and C/S in the lead-up to the 2009 eruption of Redoubt Volcano, Alaska. Geochem. Geophys. Geosyst. 13, n/a-n/a (2012).

10. Mather, T. A. Volcanoes and the environment: lessons for understanding Earth's past and future from studies of present-day volcanic emissions. $J$. Volcanol. Geotherm. Res. 304, 160-179 (2015).

11. de Moor, J. M. et al. Turmoil at Turrialba Volcano (Costa Rica): degassing and eruptive processes inferred from high-frequency gas monitoring. J. Geophys. Res. Solid Earth 121, 5761-5775 (2016).

12. Aiuppa, A. et al. The 2007 eruption of Stromboli volcano: insights from realtime measurement of the volcanic gas plume $\mathrm{CO}_{2} / \mathrm{SO}_{2}$ ratio. J. Volcanol. Geotherm. Res. 182, 221-230 (2009).

13. Aiuppa, A. et al. Forecasting Etna eruptions by real-time observation of volcanic gas composition. Geology 35, 1115 (2007).

14. Werner, C. et al. Degassing of $\mathrm{CO}_{2}, \mathrm{SO}_{2}$, and $\mathrm{H}_{2} \mathrm{~S}$ associated with the 2009 eruption of Redoubt Volcano, Alaska. J. Volcanol. Geotherm. Res. 259, 270-284 (2013).

15. Aiuppa, A. et al. Tracking formation of a lava lake from ground and space: Masaya Volcano (Nicaragua), 2014-2017. Geochem. Geophys. Geosyst. 19, 496-515 (2018).

16. Stix, J. \& de Moor, J. M. Understanding and forecasting phreatic eruptions driven by magmatic degassing. Earth, Planets Sp. 70, https://earth-planetsspace.springeropen.com/articles/10.1186/s40623-018-0855-z (2018).

17. Edmonds, M., Herd, R. A., Galle, B. \& Oppenheimer, C. M. Automated, high time-resolution measurements of $\mathrm{SO}_{2}$ flux at Soufriere Hills Volcano, Montserrat. Bull. Volcanol. 65, 578-586 (2003).
18. Galle, B. et al. A miniaturised ultraviolet spectrometer for remote sensing of $\mathrm{SO}_{2}$ fluxes: a new tool for volcano surveillance. J. Volcanol. Geotherm. Res. 119, 241-254 (2003).

19. Holland, A. S. P. S. P., Watson, I. M., Phillips, J. C., Caricchi, L. \& Dalton, M P. Degassing processes during lava dome growth: Insights from Santiaguito lava dome, Guatemala. J. Volcanol. Geotherm. Res. 202, 153-166 (2011).

20. McGonigle, A. J. S., Oppenheimer, C., Galle, B., Mather, T. A. \& Pyle, D. M. Walking traverse and scanning DOAS measurements of volcanic gas emission rates. Geophys. Res. Lett. 29, 1-4 (2002).

21. Moffat, A. J. \& Millan, M. M. The applications of optical correlation techniques to the remote sensing of $\mathrm{SO}_{2}$ plumes using sky light. Atmos. Environ. 5, 677-690 (1971)

22. Platt, U., Bobrowski, N. \& Butz, A. Ground-based remote sensing and imaging of volcanic gases and quantitative determination of multi-species emission fluxes. Geosciences 8, https://doi.org/10.3390/geosciences8020044 (2018).

23. Tamburello, G. et al. Periodic volcanic degassing behavior: the Mount Etna example. Geophys. Res. Lett. 40, 4818-4822 (2013).

24. Tamburello, G., Aiuppa, A., Kantzas, E. P., Mcgonigle, A. J. S. \& Ripepe, M Passive vs. active degassing modes at an open-vent volcano (Stromboli, Italy). Earth Planet. Sci. Lett. 359-360, 106-116 (2012).

25. Wilkes, T. et al. Ultraviolet imaging with low cost smartphone sensors: development and application of a Raspberry Pi-based UV camera. Sensors 16, 1649 (2016)

26. Aiuppa, A. et al. Total volatile flux from Mount Etna. Geophys. Res. Lett. 35 , 2004-2008 (2008).

27. D'Aleo, R. et al. Spatially resolved $\mathrm{SO}_{2}$ flux emissions from Mt Etna. Geophys. Res. Lett. 43, 7511-7519 (2016).

28. Moussallam, Y. et al. Volcanic gas emissions and degassing dynamics at Ubinas and Sabancaya volcanoes; implications for the volatile budget of the central volcanic zone. J. Volcanol. Geotherm. Res. 343, 181-191 (2017).

29. Pering, T. D. et al. A novel and inexpensive method for measuring volcanic plume water fluxes at high temporal resolution. Remote Sens. 9, 146 (2017)

30. Liu, E. J. et al. Dynamics of outgassing and plume transport revealed by proximal unmanned aerial system (UAS) measurements at Volcán Villarrica, Chile. Geochem. Geophys. Geosyst. 20, 730-750 (2019).

31. Palma, J. L., Blake, S. \& Calder, E. S. Constraints on the rates of degassing and convection in basaltic open-vent volcanoes. Geochem. Geophys. Geosyst. 12, https://agupubs.onlinelibrary.wiley.com/doi/full/10.1029/2011GC003715 (2011).

32. La Spina, A., Burton, M., Allard, P., Alparone, S. \& Muré, F. Open-path FTIR spectroscopy of magma degassing processes during eight lava fountains on Mount Etna. Earth Planet. Sci. Lett. 413, 123-134 (2015).

33. Rüdiger, J. et al. Implementation of electrochemical, optical and denuderbased sensors and sampling techniques on UAV for volcanic gas measurements: examples from Masaya, Turrialba and Stromboli volcanoes. Atmos. Meas. Tech. 11, 2441-2457 (2018).

34. Stix, J. et al. Using drones and miniaturized instrumentation to study degassing at Turrialba and Masaya Volcanoes, Central America. J. Geophys. Res. Solid Earth 123, 6501-6520 (2018).

35. Kazahaya, R., Shinohara, H., Ohminato, T. \& Kaneko, T. Airborne measurements of volcanic gas composition during unrest at Kuchinoerabujima volcano, Japan. Bull. Volcanol. 81, 7 (2019).

36. de Moor, J. M. et al. Insights on hydrothermal-magmatic interactions and eruptive processes at Poás volcano (Costa Rica) from high-frequency gas monitoring and drone measurements. Geophys. Res. Lett. 46, 1293-1302 (2019).

37. McGonigle, A. J. S. et al. Unmanned aerial vehicle measurements of volcanic carbon dioxide fluxes. Geophys. Res. Lett. 35, https://agupubs.onlinelibrary. wiley.com/doi/full/10.1029/2007GL032508 (2008).

38. Patrick, M. R. et al. Strombolian explosive styles and source conditions: Insights from thermal (FLIR) video. Bull. Volcanol. 69, 769-784 (2007).

39. Landi, P., Marchetti, E., La Felice, S., Ripepe, M. \& Rosi, M. Integrated petrochemical and geophysical data reveals thermal distribution of the feeding conduits at Stromboli volcano, Italy. Geophys. Res. Lett. 38, https://agupubs. onlinelibrary.wiley.com/doi/full/10.1029/2010GL046296 (2011).

40. Leduc, L., Gurioli, L., Harris, A., Colò, L. \& Rose-Koga, E. F. Types and mechanisms of strombolian explosions: characterization of a gas-dominated explosion at Stromboli. Bull. Volcanol. 77, 8 (2015).

41. Gaudin, D. et al. Characteristics of puffing activity revealed by ground-based, thermal infrared imaging: the example of Stromboli Volcano (Italy). Bull. Volcanol. 79, 24 (2017).

42. Salvatore, V. et al. Parameterizing multi-vent activity at Stromboli Volcano (Aeolian Islands, Italy). Bull. Volcanol. 80, 64 (2018).

43. Tournigand, P.-Y. et al. Time evolution of transient volcanic plumes: Insights from fractal analysis. J. Volcanol. Geotherm. Res. 371, 59-71 (2019).

44. Ripepe, M., Harris, A. J. L. \& Carniel, R. Thermal, seismic and infrasonic evidences of variable degassing rates at Stromboli volcano. J. Volcanol. Geotherm. Res. 118, 285-297 (2002). 
45. Vergniolle, S. \& Jaupart, C. Separated two-phase flow and basaltic eruptions. J. Geophys. Res. Solid Earth 91, 12842-12860 (1986).

46. James, M. R., Lane, S. J. \& Corder, S. B. Modelling the rapid near-surface expansion of gas slugs in low-viscosity magmas. Geol. Soc. Lond. Spec. Publ. 307, 147-167 (2008).

47. Taddeucci, J. et al. High-speed imaging of Strombolian explosions: the ejection velocity of pyroclasts. Geophys. Res. Lett. 39, 1-6 (2012).

48. Barth, A., Edmonds, M. \& Woods, A. Valve-like dynamics of gas flow through a packed crystal mush and cyclic strombolian explosions. Sci. Rep. 9, 821 (2019).

49. Suckale, J., Keller, T., Cashman, K. V. \& Persson, P. O. Flow-to-fracture transition in a volcanic mush plug may govern normal eruptions at Stromboli. Geophys. Res. Lett. 43, 12,071-12,081 (2016).

50. Pering, T. D. \& McGonigle, A. J. S. Combining spherical-cap and Taylor bubble fluid dynamics with plume measurements to characterize basaltic degassing. Geosciences 8, 42 (2018).

51. Gaudin, D. et al. Integrating puffing and explosions in a general scheme for Strombolian-style activity. J. Geophys. Res. Solid Earth 122, 1860-1875 (2017).

52. Aiuppa, A. et al. Unusually large magmatic $\mathrm{CO}_{2}$ gas emissions prior to a basaltic paroxysm. Geophys. Res. Lett. 37, 1-5 (2010).

53. Bertagnini, A., Di Roberto, A. \& Pompilio, M. Paroxysmal activity at Stromboli: lessons from the past. Bull. Volcanol. 73, 1229-1243 (2011).

54. Barberi, F., Civetta, L., Rosi, M. \& Scandone, R. Chronology of the 2007 eruption of Stromboli and the activity of the Scientific Synthesis Group. J. Volcanol. Geotherm. Res. 182, 123-130 (2009).

55. D'Oriano, C., Bertagnini, A., Cioni, R. \& Pompilio, M. Identifying recycled ash in basaltic eruptions. Sci. Rep. 4, 5851 (2015).

56. Del Bello, E. et al. Viscous plugging can enhance and modulate explosivity of strombolian eruptions. Earth Planet. Sci. Lett. 423, 210-218 (2015).

57. Capponi, A., Taddeucci, J. \& Scarlato, P. Recycled ejecta modulating Strombolian explosions. Bull. Volcanol. https://link.springer.com/article/ 10.1007/s00445-016-1001-z\#citeas (2016).

58. La Spina, A. et al. New insights into volcanic processes at Stromboli from Cerberus, a remote-controlled open-path FTIR scanner system. J. Volcanol. Geotherm. Res. 249, 66-76 (2013).

59. Andronico, D. \& Pistolesi, M. The November 2009 paroxysmal explosions at Stromboli. J. Volcanol. Geotherm. Res. 196, 120-125 (2010).

60. Burton, M. R. R., Mader, H. M. M. \& Polacci, M. The role of gas percolation in quiescent degassing of persistently active basaltic volcanoes. Earth Planet. Sci. Lett. 264, 46-60 (2007).

61. Polacci, M. et al. Degassing behaviour of vesiculated basaltic magmas: an example from Ambrym volcano. Vanuatu Arc. 233-234, 55-64 (2012).

62. Burton, M., Allard, P., Mure, F. \& La Spina, A. Magmatic gas composition reveals the source depth of slug-driven strombolian explosive activity. Science 317, 227-230 (2007).

63. Burton, $\mathrm{M}$. R. et al. $\mathrm{SO}_{2}$ flux monitoring at Stromboli with the new permanent INGV $\mathrm{SO}_{2}$ camera system: a comparison with the FLAME network and seismological data. J. Volcanol. Geotherm. Res. 300, 95-102 (2015).

64. Morrison, G. W. Characteristics and tectonic setting of the shoshonite rock association. LITHOS 13, 97-108 (1980).

65. Métrich, N., Bertagnini, A. \& Di Muro, A. Conditions of magma storage, degassing and ascent at Stromboli: new insights into the volcano plumbing system with inferences on the eruptive dynamics. J. Petrol. 51, 603-626 (2009).

66. Wilkes, T. et al. A low-cost smartphone sensor-based UV camera for volcanic $\mathrm{SO}_{2}$ emission measurements. Remote Sens. 9, 27 (2017).

67. Campion, R., Delgado-Granados, H. \& Mori, T. Image-based correction of the light dilution effect for $\mathrm{SO}_{2}$ camera measurements. J. Volcanol. Geotherm. Res. 300, 48-57 (2015).

68. Kern, C., Werner, C., Elias, T., Sutton, A. J. \& Lübcke, P. Applying UV cameras for $\mathrm{SO}_{2}$ detection to distant or optically thick volcanic plumes. $J$. Volcanol. Geotherm. Res. 262, 80-89 (2013).

69. McGonigle, A. J. S., Hilton, D. R., Fischer, T. P. \& Oppenheimer, C. Plume velocity determination for volcanic $\mathrm{SO}_{2}$ flux measurements. Geophys. Res. Lett. 32, 1-4 (2005)

70. Williams-Jones, G. et al. Accurately measuring volcanic plume velocity with multiple UV spectrometers. Bull. Volcanol. 68, 328-332 (2006).
71. Kantzas, E. P., McGonigle, A. J. S., Tamburello, G., Aiuppa, A. \& Bryant, R. G. Protocols for UV camera volcanic $\mathrm{SO}_{2}$ measurements. J. Volcanol. Geotherm. Res. 194, 55-60 (2010).

72. Gliß, J. et al. Pyplis-a python software toolbox for the analysis of $\mathrm{SO}_{2}$ camera images for emission rate retrievals from point sources. Geosciences 7, 134 (2017).

73. McGonigle, A. J. S. et al. Ultraviolet imaging of volcanic plumes: a new paradigm in volcanology. Geosciences 7, 68 (2017).

74. Aiuppa, A., Federico, C., Giudice, G. \& Gurrieri, S. Chemical mapping of a fumarolic field: La Fossa Crater, Vulcano Island (Aeolian Islands, Italy). Geophys. Res. Lett. 32, L13309 (2005).

75. Tamburello, G. Ratiocalc: software for processing data from multicomponent volcanic gas analyzers. Comput. Geosci. 82, 63-67 (2015).

\section{Acknowledgements}

T.D.P. gratefully acknowledges the support of the Royal Society (RG170226). E.J.L. was supported by a Leverhulme Early Career Fellowship. T.R. and K.W. were supported by EPSRC through the CASCADE Programme Grant (EP/R009953/1). This research was enabled through the Alfred P. Sloan Foundation's support of the Deep Carbon Observatory Deep Earth Carbon Degassing program (DECADE). A.A. acknowledges funding from the Deep Carbon Observatory, from Muir (Grant N. 2017LMNLAW), and from the Italian Civil Protection (DCP) through sub-contract with Università di Firenze (n. 2089/ 2019). AMcG acknowledges support from the Rolex Institute.

\section{Author contributions}

T.D.P. devised the study concept. T.D.P., E.J.L., K.W. and T.C.W. conducted the fieldwork. K.W., T.R. and E.J.L. devised UAS methods. T.D.P., T.C.W. and A.J.S.M. devised UV camera methods. G.T., M.B. and A.A. provided Multi-GAS data. All contributed to the manuscript process.

\section{Competing interests}

The authors declare no competing interests.

\section{Additional information}

Supplementary information is available for this paper at https://doi.org/10.1038/s41467 020-16862-w.

Correspondence and requests for materials should be addressed to T.D.P.

Peer review information Nature Communications thanks Giovanni Chiodini, PierreJean Gauthier and the other, anonymous, reviewer(s) for their contribution to the peer review of this work.

Reprints and permission information is available at http://www.nature.com/reprints

Publisher's note Springer Nature remains neutral with regard to jurisdictional claims in published maps and institutional affiliations.

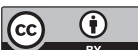

Open Access This article is licensed under a Creative Common Attribution 4.0 International License, which permits use, sharing, adaptation, distribution and reproduction in any medium or format, as long as you give appropriate credit to the original author(s) and the source, provide a link to the Creative Commons license, and indicate if changes were made. The images or other third party material in this article are included in the article's Creative Commons license, unless indicated otherwise in a credit line to the material. If material is not included in the article's Creative Commons license and your intended use is not permitted by statutory regulation or exceeds the permitted use, you will need to obtain permission directly from the copyright holder. To view a copy of this license, visit http://creativecommons.org/ licenses/by/4.0/.

(C) The Author(s) 2020 